\title{
Article \\ Characteristics of and Influencing Factors of Hydrochemistry and Carbon/Nitrogen Variation in the Huangzhouhe River Basin, a World Natural Heritage Site
}

\author{
Chenpeng $\mathrm{Hu}{ }^{1,2}$, Ziqi Liu ${ }^{1,2}$, Kangning Xiong ${ }^{1,2, *}$, Xiaoxi Lyu ${ }^{1,2}$, Yuan Li ${ }^{1,2}$ and Renkai Zhang ${ }^{1,2}$ \\ 1 School of Karst Science, Guizhou Normal University, Guiyang 550001, China; hcpmax@163.com (C.H.); \\ 201511004@gznu.edu.cn (Z.L.); karstlv@gznu.edu.cn (X.L.); liyuan7pro@163.com (Y.L.); \\ zhangrk9818@163.com (R.Z.) \\ 2 State Engineering Technology Institute for Karst Desertification Control, Guiyang 550001, China \\ * Correspondence: xiongkn@163.com
}

check for

updates

Citation: Hu, C.; Liu, Z.; Xiong, K.; Lyu, X.; Li, Y.; Zhang, R.

Characteristics of and Influencing

Factors of Hydrochemistry and

Carbon/Nitrogen Variation in the Huangzhouhe River Basin, a World Natural Heritage Site. Int. J. Environ. Res. Public Health 2021, 18, 13169. https://doi.org/10.3390/ ijerph182413169

Academic Editors: Layla Ben Ayed, Eleni Golomazou, Panagiotis Karanis, Patrick Scheid, Ourania Tzoraki, Anna Lass and Muhammad Shahid Iqbal

Received: 1 November 2021 Accepted: 12 December 2021 Published: 14 December 2021

Publisher's Note: MDPI stays neutral with regard to jurisdictional claims in published maps and institutional affiliations.

Copyright: (c) 2021 by the authors. Licensee MDPI, Basel, Switzerland. This article is an open access article distributed under the terms and conditions of the Creative Commons Attribution (CC BY) license (https:// creativecommons.org/licenses/by/ $4.0 /)$.

\begin{abstract}
In karst areas, the characteristics of water chemistry and carbon and nitrogen are of great significance to basic research. The contents of $\mathrm{Ca}^{2+}, \mathrm{Mg}^{2+}, \mathrm{K}^{+}, \mathrm{Na}^{+}, \mathrm{HCO}_{3}{ }^{-}, \mathrm{SO}_{4}{ }^{2-}, \mathrm{NO}_{3}{ }^{-}$, $\mathrm{Cl}^{-}$, dissolved organic carbon (DOC), and total nitrogen (TN) in water samples from 18 rivers and 14 springs in the Huangzhouhe River Basin were determined. The results showed that the water chemistry type in the Huangzhouhe River Basin is $\mathrm{HCO}_{3}-\mathrm{Ca}-\mathrm{Mg}$. The chemical composition is mainly affected by dolomite weathering and also by ion exchange and other human activities. The river and spring DIC remain at the same level in the upper and middle reaches and decrease in the lower reaches. The $\mathrm{NO}_{3}-\mathrm{N}$ and $\mathrm{TN}$ of river water and $\mathrm{TN}$ of spring water increase in the middle reaches, while $\mathrm{NO}_{3}-\mathrm{N}$ of spring water decreases in the lower reaches. The DOC in the basin increases with the increase of $\mathrm{SO}_{4}{ }^{2-}$ and $\mathrm{Cl}^{-}$, mainly due to the human influence of agricultural and domestic sewage. In the basin, the $\mathrm{NO}_{3}-\mathrm{N}$ and $\mathrm{TN}$ in spring water are larger, and the DOC in river water is larger, mainly because there are more phytoplankton and human activities in the river water. The carbon and nitrogen in the Huangzhouhe River Basin are mainly $\mathrm{HCO}_{3}{ }^{-}$and $\mathrm{NO}_{3}{ }^{-}$ions. The evaluation of $\mathrm{pH}, \mathrm{Cl}^{-}, \mathrm{NO}_{3}-\mathrm{N}, \mathrm{SO}_{4}{ }^{2-}$, and TDS shows that the water quality is good and the ecological environment is good.
\end{abstract}

Keywords: water chemistry; dolomite; chemical weathering; dissolved organic carbon; total nitrogen; Huangzhouhe River

\section{Introduction}

The input of terrestrial erosion material from rivers to the ocean is a key part of the biogeochemical cycle. River chemistry is influenced by many natural geochemical processes such as climate, structure, weathering, and vegetation cover [1-4]; lithology (rock weathering) is the dominant factor in these processes because rock is the main source of dissolved load in river water [5,6]. The content and distribution characteristics of ions in rivers are influenced and controlled by many factors such as precipitation, temperature, topography, altitude, recharge type, runoff and discharge processes, land use type, and surface lithology. In the Garhwal Bhagirathi watershed, chemical parameters, anions, and cations are related to geomorphological parameters and land cover parameters, and they change with the season [7]. The characteristics of water chemistry and their variation can indicate the main ion sources of the water body and reflect the influence of human activities on water environments. The inorganic carbon dissolution load in river water comes from different sources: rock dissolution, precipitation, and human input [8].

River DOC and TN mainly come from soil leaching [9,10], complex biological processes (e.g., production and release of bacteria and phytoplankton, and feeding of zooplankton) [11-13], and human input [14]. The DOC content affects aquatic communities [15] and 
facilitates heavy metal migration in river water by forming organic complexes $[16,17]$, and may lead to enrichment with toxic metals [18]. The DOC is an important part of the global carbon cycle, and is related to the environment and climate change [19-21]. Dissolved organic carbon, as an indicator of organic matter levels, can reflect the extent of organic pollution in rivers and is closely related to water quality [22,23]. It is well known that $\mathrm{Cl}^{-}$, dissolved inorganic nitrogen (DIN), and $\mathrm{SO}_{4}{ }^{2-}$ are mostly derived from human inputs $[8,24]$. Abnormal changes in climate and temperature also impact carbon and nitrogen species. For example, bacterial communities in Poyang Lake are sensitive to DOC and $\mathrm{NO}_{3}{ }^{-}$contents in the dry season [25]. On the one hand, waste input into rivers affects the river's hydrochemical properties and may interfere with natural geochemical processes and accelerate weathering processes [26,27]. On the other hand, river carbon and nitrogen concentrations can be directly increased [28-30].

In the hydrological cycle, surface water and groundwater are interdependent, mutually restricted, and independent. For example, the groundwater system of Abadir Farm is invaded by shallow groundwater and Basaka Lake [31]. Dinka [32] found that when surface water and groundwater are polluted, the upper freshwater layer is exchanged with the deeper water, and the frequent exchange of groundwater and river water increases the risk of water pollution. The high content of organic carbon in wastewater can lead to a large amount of microbial growth, making groundwater unsuitable for residential use. The variation in the characteristics of water chemistry and carbon and nitrogen contents not only reflects the ecological evolution characteristics of the region, but also affects the ecological security of the downstream regions.

In the carbonate regions of the world, dolomite is widely distributed as limestone. China is dominated by limestone, but dolomite, dolomitic tuff, and ash dolomite account for $25.7 \%$ of the total distribution of carbonate rocks in China. Most research in China has focused on limestone karst areas, with less research on dolomite karst areas. Large areas of dolomite are also exposed in some other provinces in China, mainly as grey dolomite or dolomite interbedded with limestone; pure dolomite up to $1100 \mathrm{~m}$ thick is only found in Shibing, Guizhou [33]. Through the study of the temporal and spatial dynamics of the contents of anions and cations in the Huangzhouhe River Basin, we revealed the hydrogeochemical characteristics of typical subtropical dolomite basins in this study. The objectives of this study were to (1) analyze the hydrochemical characteristics of river water and spring water in the basin, (2) determine the variation in water $\mathrm{C}$ and $\mathrm{N}$ concentrations and their relationship, and (3) clarify the effects of human input on water chemistry and water quality.

\section{Materials and Methods}

\subsection{Study Area}

The Huangzhouhe River Basin in Guizhou Province is located in a World Natural Heritage Protection Area (Figure 1). It is a complete and typical dolomite karst basin, and is a natural site for studying the weathering of dolomite rocks. In the Huangzhouhe River Basin, limestone is exposed in $8 \%$ of the area and dolomite is exposed in $92 \%$ of the area. The exposed strata are the Cambrian Gaotai, Loushanguan, and Shilengshui formations, and a small amount is the Qingxudong formation. It flows from the eastern heritage site buffer to the southwest core area, the upper part is a wide valley. Above the Baiduo is the upstream, above the Qingcaitang is the midstream, and below is the downstream. A dolomite landform developed strongly in the basin, and the landform is broken. Due to river-cutting and erosion, the area developed into a typical deep subtropical karst gorge landform. The Huangzhouhe River Basin has a subtropical humid monsoon climate, with rainy and hot periods and abundant precipitation. The annual average temperature is $14-16{ }^{\circ} \mathrm{C}$, the annual rainfall is $1060-1200 \mathrm{~mm}$, the annual average discharge is $4.2 \mathrm{~m}^{3} / \mathrm{s}$, and the annual average evaporation is $1078.42 \mathrm{~mm}$. The topography of Shibing Karst World Natural Heritage Site in which the Huangzhouhe River is located high in the northwest and low in the southeast, with a core area of $10,280 \mathrm{hm}^{2}$, a buffer area of $18,015 \mathrm{hm}^{2}$, 
and a total area of $28,295 \mathrm{hm}^{2}$ [33]. The study area is a World Natural Heritage Site. It has a pure natural ecological environment, mainly vegetated by trees and shrubs. The middle and upper reaches of the Huangzhouhe River are located in the buffer zone, with a high population density and diverse land use types, mainly including dry arable land, paddy field, woodland, and shrub forest, where the ecological environment is disturbed by human beings. There is the potential for large amounts of pollutants to flow from the buffer zone into the core area, thereby impacting the ecological health of the site. Therefore, it is of considerable value to study the hydrochemistry, carbon and nitrogen characteristics, and their influencing factors on the Huangzhouhe River for the protection of world natural heritage.
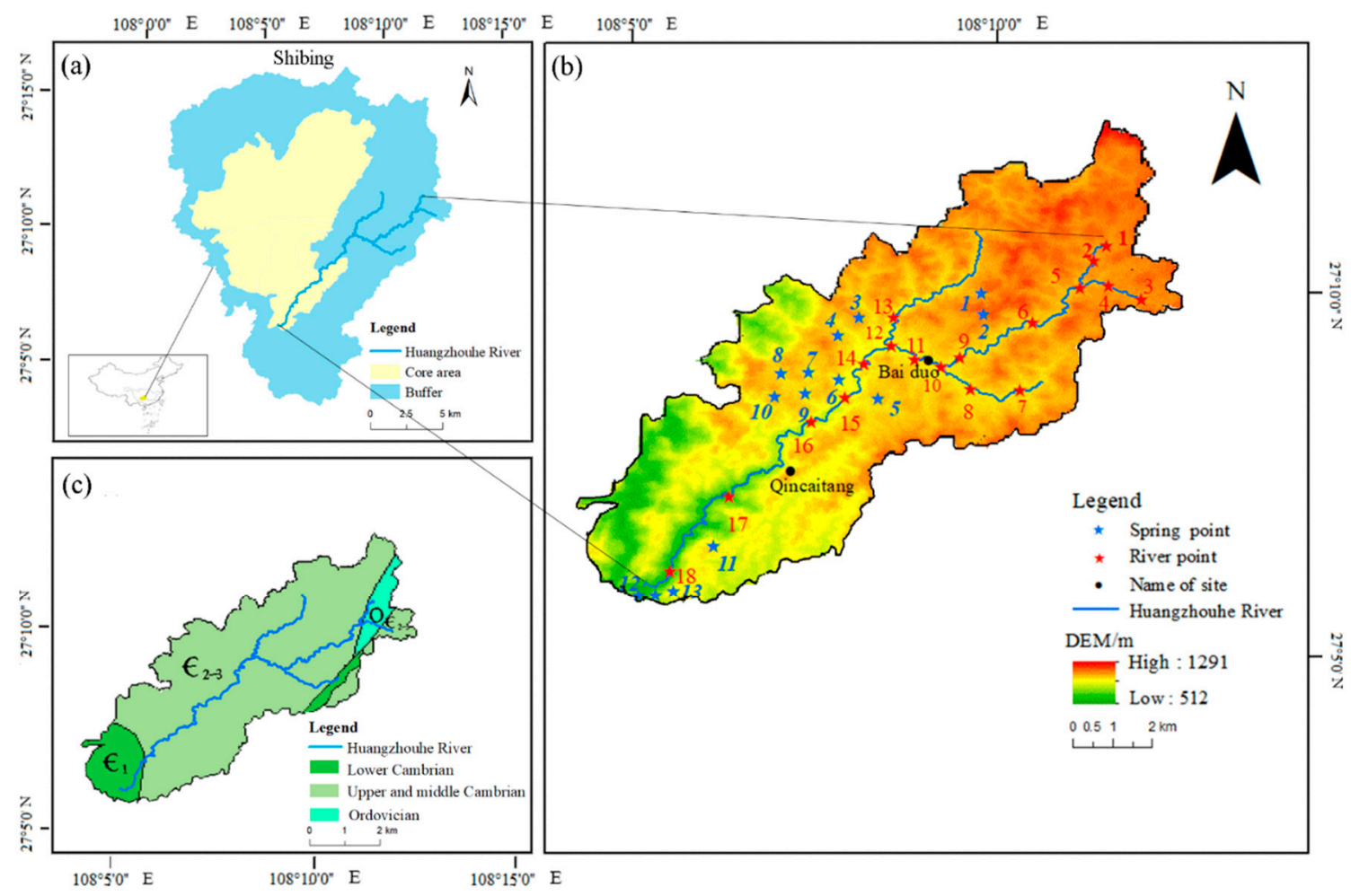

Figure 1. Location of sampling sites in the Huangzhouhe River Basin. (a) Buffer and core areas of the Shingbing River. (b)The Huangzhouhe River Basin and sampling sites. (c) Stratigraphy of the Huangzhouhe River Basin.

\subsection{Water Sampling and Analysis}

The sampling was conducted in January and July 2021, taking the Huangzhouhe River basin as a whole and collecting 18 river samples from downstream to upstream, tributaries and main streams, and 14 spring samples within the basin, for a total of 32 samples. The samples were washed with a $1 \mathrm{~mol} \cdot \mathrm{L}^{-1}$ solution of analytically pure $\mathrm{HNO}_{3}$, then rinsed clean with pure water and dried to ensure that the ions in the water sample did not adhere to the bottle wall. The collected samples were filtered on the same day $(0.45 \mu \mathrm{m}$ Millipore membrane), and the filtered samples were packed into different pretreatment polyethylene bottles. Cationic polyethylene bottles were acidified on site with 1:1 pure nitric acid to $\mathrm{pH}$ $<2$; the contents of the anionic polyethylene bottles, and TN and DOC polyethylene bottles were added directly to the filtered water samples, and the polyethylene bottles were sealed with sealing film. The collected samples were stored at low temperature in the field in a refrigerated box and quickly sent to the laboratory.

The water temperature $\left({ }^{\circ} \mathrm{C}\right), \mathrm{pH}$, and conductivity $\left(\mathrm{EC}, \mu \mathrm{S} \cdot \mathrm{cm}^{-1}\right)$ of the dripping water were tested in the field with a HQ40d portable water quality analyzer $(\mathrm{HACH}$, Loveland, $\mathrm{CO}, \mathrm{USA})$, and the $\mathrm{HCO}_{3}{ }^{-}\left(\mathrm{mmol} \cdot \mathrm{L}^{-1}\right)$ concentration of the water samples was determined through titration, with the value recorded separately with an alkalinity meter 
(Merck, Germany). The concentrations of anions $\left(\mathrm{Cl}^{-}, \mathrm{NO}_{3}{ }^{-}\right.$, and $\left.\mathrm{SO}_{4}{ }^{2-}\right)$ were determined by ion chromatography (IC, DX-120, Dionex, Germany). An Optima-2100DV full-spectrum, direct-reading ICP-OES (Perkin-Elmer, USA) was used to determine the concentrations of $\mathrm{K}^{+}, \mathrm{Na}^{+}, \mathrm{Ca}^{2+}$, and $\mathrm{Mg}^{2+}$ in dripping water samples, having a detection accuracy of $0.001 \mathrm{mg} \cdot \mathrm{L}^{-1}$ and a relative standard deviation of $<2 \%$. The detection limits for all ions were less than $0.1 \mathrm{mg} / \mathrm{L}$. DOC and TN concentrations were determined using a Shimadzu TOC-VCPH total organic carbon analyzer with a relative standard deviation of $<1.5 \%$. Each sample value represents the average of two consecutive measurements. The measurement error was less than $1 \%$.

\subsection{Data Processing}

We used IBM SPSS Statistics 26 (IBM, Armonk, NY, USA) and Excel (Microsoft Corporation, Albuquerque, NM, USA) to complete the statistical analysis, and Aq-QA (version 1.1) water chemistry analysis software (RockWare, Inc., Golden, CO, USA) and Origin2021b for plotting (OriginLab. Northampton, MA, USA).

\section{Results}

\subsection{Physicochemical Parameters and Hydrochemical Type}

The water samples in the Huangzhouhe River Basin are generally weakly alkaline, with a $\mathrm{pH}$ between 6.98 and 8.99 . The $\mathrm{pH}$ of the river during the rainy season is slightly higher than during the dry season. The TDS is $202.30-488.50 \mathrm{mg} \cdot \mathrm{L}^{-1}$, with an average of $338.4 \mathrm{mg} \cdot \mathrm{L}^{-1}$, in the rainy season and $348.58 \mathrm{mg} \cdot \mathrm{L}^{-1}$ in the dry season. Table 1 shows that the ion content in the rainy season is slightly higher than that in the dry season.

Table 1. Statistics of the hydrochemical parameters of the Huangzhouhe River Basin $\left(\mathrm{mg} \cdot \mathrm{L}^{-1}\right)$.

\begin{tabular}{ccccccccccc}
\hline Dry & $\mathbf{p H}$ & $\mathbf{C a}^{2+}$ & $\mathbf{M g}^{\mathbf{2 +}}$ & $\mathbf{K}^{+}$ & $\mathbf{N a}^{+}$ & $\mathbf{C l}^{-}$ & $\mathbf{N O}_{3}{ }^{-}$ & $\mathbf{S O}_{4}{ }^{2-}$ & $\mathbf{H C O}_{3}{ }^{-}$ & $\mathbf{T D S}^{-}$ \\
\hline Minimum & 6.98 & 46.15 & 16.56 & 0.11 & 0.08 & 0.43 & 1.20 & 4.63 & 274.50 & 265.60 \\
Maximum & 8.19 & 101.57 & 80.94 & 5.13 & 5.29 & 5.79 & 8.51 & 28.53 & 469.70 & 488.50 \\
Average & 7.46 & 70.25 & 40.12 & 1.40 & 1.10 & 2.27 & 3.68 & 16.19 & 367 & 348.58 \\
SD & 0.29 & 13.69 & 13.30 & 1.26 & 1.11 & 1.31 & 1.99 & 6.05 & 48.71 & 51.01 \\
\hline Wet & $\mathbf{p H}$ & $\mathbf{C a}^{2+}$ & $\mathbf{M g}^{2+}$ & $\mathbf{K}^{+}$ & $\mathbf{N a}^{+}$ & $\mathbf{C l}^{-}$ & $\mathbf{N O}_{3}^{-}$ & $\mathbf{S O}_{4}{ }^{2-}$ & $\mathbf{H C O}_{3}^{-}$ & $\mathbf{T D S}^{-}$ \\
\hline Minimum & 7.19 & 45.47 & 34.66 & 0.49 & 0.55 & 0.92 & 2.61 & 8.84 & 268.4 & 202.30 \\
Maximum & 8.99 & 122.40 & 52.93 & 3.37 & 2.59 & 5.45 & 26.64 & 26.08 & 469.7 & 440.20 \\
Average & 8.16 & 89.71 & 43.10 & 1.52 & 1.31 & 2.60 & 8.84 & 17.12 & 355.3 & 338.40 \\
$\quad$ SD & 0.48 & 15.54 & 4.40 & 0.87 & 0.62 & 1.20 & 7.67 & 5.44 & 51.53 & 54.69 \\
\hline
\end{tabular}

$\mathrm{Ca}^{2+}, \mathrm{Mg}^{2+}$, and $\mathrm{HCO}_{3}{ }^{-}$are the dominant ions in the Huangzhouhe River Basin (Figure 2). The decreasing order of cations in the river is $\mathrm{Ca}^{2+}>\mathrm{Mg}^{2+}>\mathrm{K}^{+}>\mathrm{Na}^{+}$, with $\mathrm{Ca}^{2+}$ and $\mathrm{Mg}^{2+}$ accounting for about $97.93 \%$ of the cations. The decreasing order of anion concentration is $\mathrm{HCO}_{3}{ }^{-}>\mathrm{SO}_{4}{ }^{2-}>\mathrm{NO}_{3}{ }^{-}>\mathrm{Cl}^{-}$, with $\mathrm{HCO}_{3}{ }^{-}$accounting for about $94.31 \%$. The cations in the spring are $\mathrm{Ca}^{2+}>\mathrm{Mg}^{2+}>\mathrm{K}^{+}>\mathrm{Na}^{+}$, with $\mathrm{Ca}^{2+}$ and $\mathrm{Mg}^{2+}$ accounting for about $97.83 \%$ of the cations. The anion concentration is $\mathrm{HCO}_{3}{ }^{-}>\mathrm{SO}_{4}{ }^{2-}>\mathrm{NO}_{3}{ }^{-}>$ $\mathrm{Cl}^{-}$, with $\mathrm{HCO}_{3}{ }^{-}$accounting for about $92.05 \%$ of the total. The box plot in Figure 2 shows that the $\mathrm{Na}^{+}, \mathrm{K}^{+}$, and $\mathrm{Cl}^{-}$contents in the river water are roughly the same as those in groundwater, so it can be inferred that atmospheric precipitation is the main source of recharge. The $\mathrm{Ca}^{2+}$ and $\mathrm{Mg}^{2+}$ contents in river water are slightly higher than those in spring water, and the concentration of $\mathrm{HCO}_{3}{ }^{-}$in spring water is higher than that in river water, which is related to the longer time of water-rock interaction in spring water. $\mathrm{pH}$ and $\mathrm{SO}_{4}{ }^{2-}$ and $\mathrm{NO}_{3}{ }^{-}$contents in spring water are also higher than those in river water. 

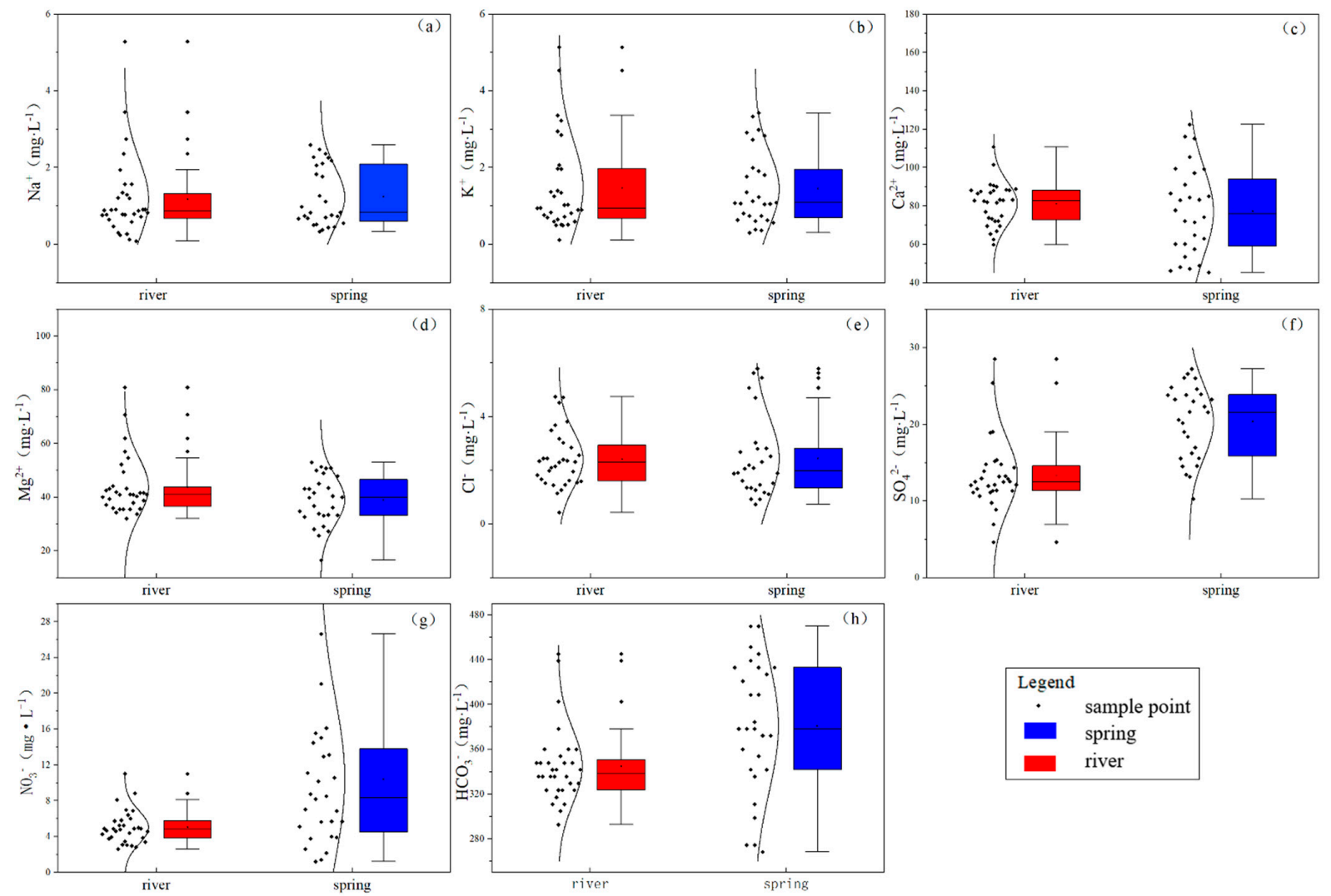

Figure 2. Ion box diagram for the water samples: $(\mathbf{a}-\mathbf{h})$ comparison of ion contents between river water and spring water.

The Piper trilinear map, which is divided into nine zones according to ion content, assigns different positions in the diamond to different water chemistries, which can objectively reflect the water chemistry of the region. The trilinear diagram shows that surface water and groundwater have basically the same ion positions, with all having a carbonic acid content of more than $80 \%$, calcium and magnesium contents in the range of $30 \%$ to $70 \%$, and the sum of carbonic acid and calcium and magnesium contents accounting for more than $60 \%$, indicating the same water-rock action. The water chemistry type is mainly $\mathrm{HCO}_{3}-\mathrm{Ca}-\mathrm{Mg}$ because the study area is controlled by karst area carbonate rocks (Figure 3). After long-term water-rock interaction, groundwater is more concentrated in the lower left corner of the Piper three-line diagram, which is consistent with the results of Nandong karst water in December [34].
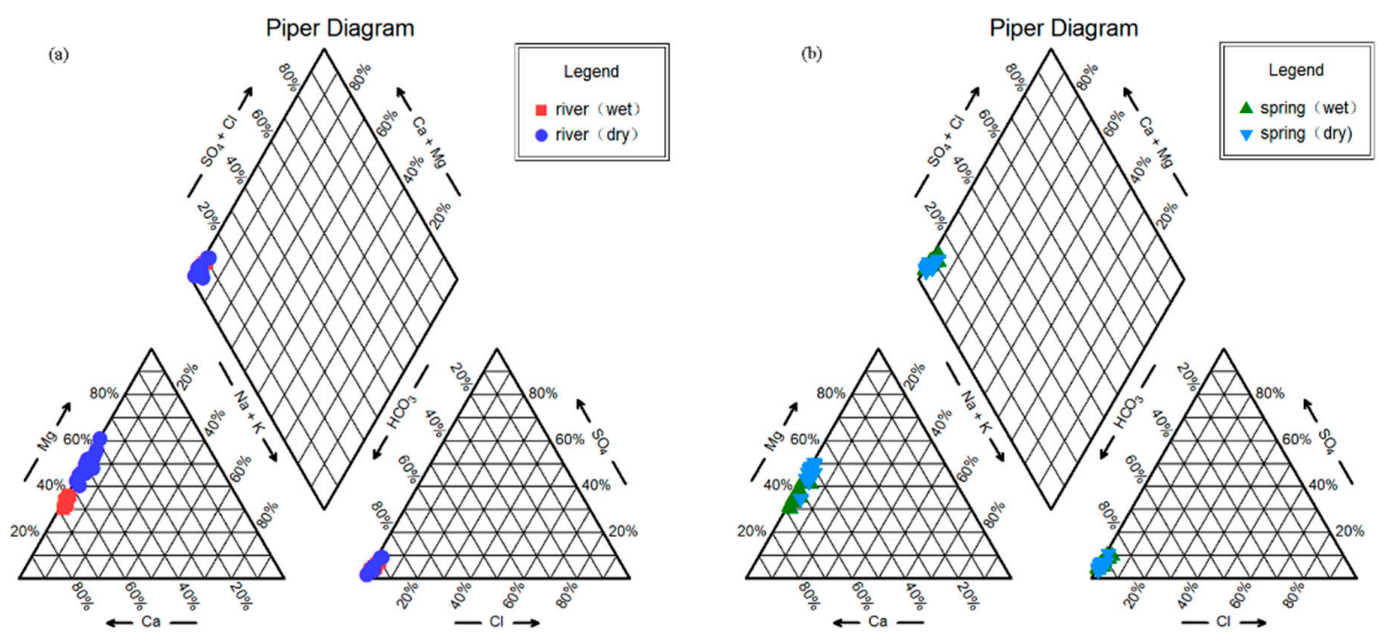

Figure 3. Chemistry Piper diagram of the river (a) and spring (b) water in the Huangzhouhe River Basin. 


\subsection{C and N Types and Distribution}

The DIC in natural water bodies is mainly derived from $\mathrm{CO}_{2}$ input from air and soil and the dissolution or precipitation of carbonate rocks [35]. Within the Huangzhouhe River Basin, which is mainly subject to carbonate rock weathering, DIC is mainly derived from dolomite weathering. The DIC in the water column occurs mainly in the form of $\mathrm{HCO}_{3}{ }^{-}, \mathrm{CO}_{3}{ }^{2-}, \mathrm{CO}_{2}$, and $\mathrm{H}_{2} \mathrm{CO}_{3} . \mathrm{HCO}_{3}{ }^{-}$is highly significantly positively correlated with DIC, accounting for $80.39 \%$ of the DIC [36]. In this paper, the $\mathrm{HCO}_{3}{ }^{-}$content is used to represent the DIC. The TN in a river is input through three main pathways: external input, internal organic matter cycling, and substrate release [37]. In springs, TN is mainly provided from rainfall and overlying vegetation activities.

Table 2 shows the variation law of the concentrations of various forms of carbon and nitrogen concentration in the Huangzhouhe River Basin. In the dry season, the TN content of the river from upstream to downstream is $0.62 \sim 1.91 \mathrm{mg} \cdot \mathrm{L}^{-1}$, the $\mathrm{NO}_{3}-\mathrm{N}$ content is $0.49 \sim 1.19 \mathrm{mg} \cdot \mathrm{L}^{-1}$, the DIC content is $305 \sim 445.3 \mathrm{mg} \cdot \mathrm{L}^{-1}$, and the DOC content is $2.04 \sim 4.52 \mathrm{mg} \cdot \mathrm{L}^{-1}$. The spring water TN content is $0.29 \sim 2.63 \mathrm{mg} \cdot \mathrm{L}^{-1}$, the $\mathrm{NO}_{3}-\mathrm{N}$ content is $0.15 \sim 1.92 \mathrm{mg} \cdot \mathrm{L}^{-1}$, the DOC content is $1.48 \sim 4.85 \mathrm{mg} \cdot \mathrm{L}^{-1}$, and the DIC content is $274.5 \sim 469.7 \mathrm{mg} \cdot \mathrm{L}^{-1}$. In the rainy season, the TN content of the river from upstream to downstream is $1.22 \sim 3.23 \mathrm{mg} \cdot \mathrm{L}^{-1}$, the $\mathrm{NO}_{3}-\mathrm{N}$ content is $0.77 \sim 1.29 \mathrm{mg} \cdot \mathrm{L}^{-1}$, the DIC content is $292.87 \sim 378.2 \mathrm{mg} \cdot \mathrm{L}^{-1}$, and the DOC content is $2.57 \sim 4.81 \mathrm{mg} \cdot \mathrm{L}^{-1}$. Spring water's TN content is $1.62 \sim 3.78 \mathrm{mg} \cdot \mathrm{L}^{-1}$, its $\mathrm{NO}_{3}-\mathrm{N}$ content is $0.89 \sim 2.51 \mathrm{mg} \cdot \mathrm{L}^{-1}$, the DOC content is $1.66 \sim 3.36 \mathrm{mg} \cdot \mathrm{L}^{-1}$, and the DIC content is 274.5 469.7 mg. $\mathrm{L}^{-1}$. The $\mathrm{NO}_{3}-\mathrm{N}$ and TN contents in river water are higher in the middle reaches, DIC content is slightly lower in the downstream area, and DOC content decreases along the river from the upper to lower reaches. In spring water, $\mathrm{NO}_{3}-\mathrm{N}$, $\mathrm{TN}$, and DIC contents are lower in the downstream area, and the DOC content is higher in the middle reaches. In general, the carbon and nitrogen contents of spring water are higher than those in river water.

Table 2. $\mathrm{C}$ and $\mathrm{N}$ species in the Huangzhouhe River Basin $\left(\mathrm{mg} \cdot \mathrm{L}^{-1}\right)$.

\begin{tabular}{|c|c|c|c|c|c|c|c|}
\hline & \multirow{2}{*}{ Parameter } & \multicolumn{2}{|c|}{ Upper Huangzhouhe } & \multicolumn{2}{|c|}{ Middle Huangzhouhe } & \multicolumn{2}{|c|}{ Lower Huangzhouhe } \\
\hline & & Range & Mean Value & Range & Mean Value & Range & Mean Value \\
\hline \multirow{4}{*}{$\begin{array}{l}\text { River } \\
\text { (dry) }\end{array}$} & DOC & $2.46-4.52$ & 3.33 & $2.34-3.77$ & 2.90 & $2.04-3.54$ & 2.79 \\
\hline & DIC & $305-445.3$ & 351.36 & $317.2-439.2$ & 356.85 & $323.3-329.4$ & 326.35 \\
\hline & $\mathrm{NO}_{3}-\mathrm{N}$ & $0.49-0.79$ & 0.63 & 0.76-1.19 & 0.92 & $0.64-0.7$ & 0.67 \\
\hline & $\mathrm{TN}$ & $0.62-1.33$ & 0.9 & $1.04-1.91$ & 1.26 & $0.89-0.93$ & 0.91 \\
\hline \multirow{4}{*}{$\begin{array}{l}\text { River } \\
\text { (wet) }\end{array}$} & DOC & $2.57-4.81$ & 3.38 & $2.82-3.96$ & 3.37 & 2.86 & 2.86 \\
\hline & DIC & $323.3-378.2$ & 347.7 & $311.1-347.7$ & 324.83 & 292.87 & 292.8 \\
\hline & $\mathrm{NO}_{3}-\mathrm{N}$ & $0.85-1.99$ & 1.20 & $0.77-1.29$ & 1.01 & 0.90 & 0.90 \\
\hline & $\mathrm{TN}$ & $1.22-3.23$ & 1.89 & $1.29-1.97$ & 1.54 & 1.06 & 1.06 \\
\hline \multirow{4}{*}{$\begin{array}{c}\text { Spring } \\
\text { (dry) }\end{array}$} & DOC & $1.56-1.93$ & 1.75 & $1.77-4.85$ & 3.09 & $1.48-1.8$ & 1.70 \\
\hline & DIC & $378.2-433.1$ & 405.65 & $335.5-469.7$ & 407.16 & $274.5-408.7$ & 341.6 \\
\hline & $\mathrm{NO}_{3}-\mathrm{N}$ & $0.15-1.92$ & 1.04 & $0.27-1.4$ & 1 & $0.7-0.88$ & 0.81 \\
\hline & $\mathrm{TN}$ & $0.59-2.99$ & 1.44 & $0.62-2.63$ & 1.50 & $0.83-1.55$ & 1.17 \\
\hline \multirow{4}{*}{$\begin{array}{c}\text { Spring } \\
\text { (wet) }\end{array}$} & DOC & $1.90-2.33$ & 2.11 & $2.11-4.23$ & 3.36 & $1.66-1.86$ & 1.75 \\
\hline & DIC & $420.9-433.1$ & 427 & $274.5-469.7$ & 390.4 & $268.4-372.1$ & 312.63 \\
\hline & $\mathrm{NO}_{3}-\mathrm{N}$ & 0.59-1.55 & 1.07 & 0.89-6.01 & 3.54 & $1.15-4.75$ & 2.43 \\
\hline & TN & $1.84-2.16$ & 2 & $1.62-3.78$ & 2.97 & $1.99-3.32$ & 2.70 \\
\hline
\end{tabular}

DIC: dissolved inorganic carbon; DOC: dissolved organic carbon; $\mathrm{NO}_{3}-\mathrm{N}$ : nitrate; $\mathrm{TN}$ : dissolved organic nitrogen.

\section{Discussion}

\subsection{Analysis of Major Ion Sources}

Correlation analysis between anions and cations can reflect the material origin of the ions and the characteristics of the chemical reactions they underwent. Ions with stronger correlations may be from the same material or may have undergone the same chemical reaction process. The $\mathrm{Ca}^{2+}$ and $\mathrm{Mg}^{2+}$ in the river water in the basin are strongly correlated, as are the $\mathrm{K}^{+}$and $\mathrm{Na}^{+}$, and $\mathrm{Cl}^{-}$and $\mathrm{SO}_{4}{ }^{2-}$ (Figure $4 \mathrm{a}$ ), which indicates that $\mathrm{Ca}^{2+}$ and $\mathrm{Mg}^{2+}$, 
$\mathrm{Cl}^{-}$and $\mathrm{SO}_{4}{ }^{2-}$, and $\mathrm{K}^{+}$and $\mathrm{Na}+$ came from different substances or underwent the same chemical process. The analysis is provided below. In the basin spring water, TDS and $\mathrm{HCO}_{3}{ }^{-}$are extremely correlated (Figure $4 \mathrm{~b}$ ) and show strong correlation with $\mathrm{Ca}^{2+}$ and $\mathrm{Mg}^{2+}$, where $\mathrm{Ca}^{2+}, \mathrm{Mg}^{2+}$ and $\mathrm{HCO}_{3}{ }^{-}$are all major ions. $\mathrm{HCO}_{3}{ }^{-}$correlates with both $\mathrm{Ca}^{2+}$ and $\mathrm{Mg}^{2+}$, indicating a similar origin. In the basin water samples, $\mathrm{Ca}^{2+}$ shows an extremely strong correlation with $\mathrm{Mg}^{2+}$ and TDS with $\mathrm{HCO}_{3}{ }^{-}$, indicating that carbonate rocks are the main factor controlling water chemistry in the study area.
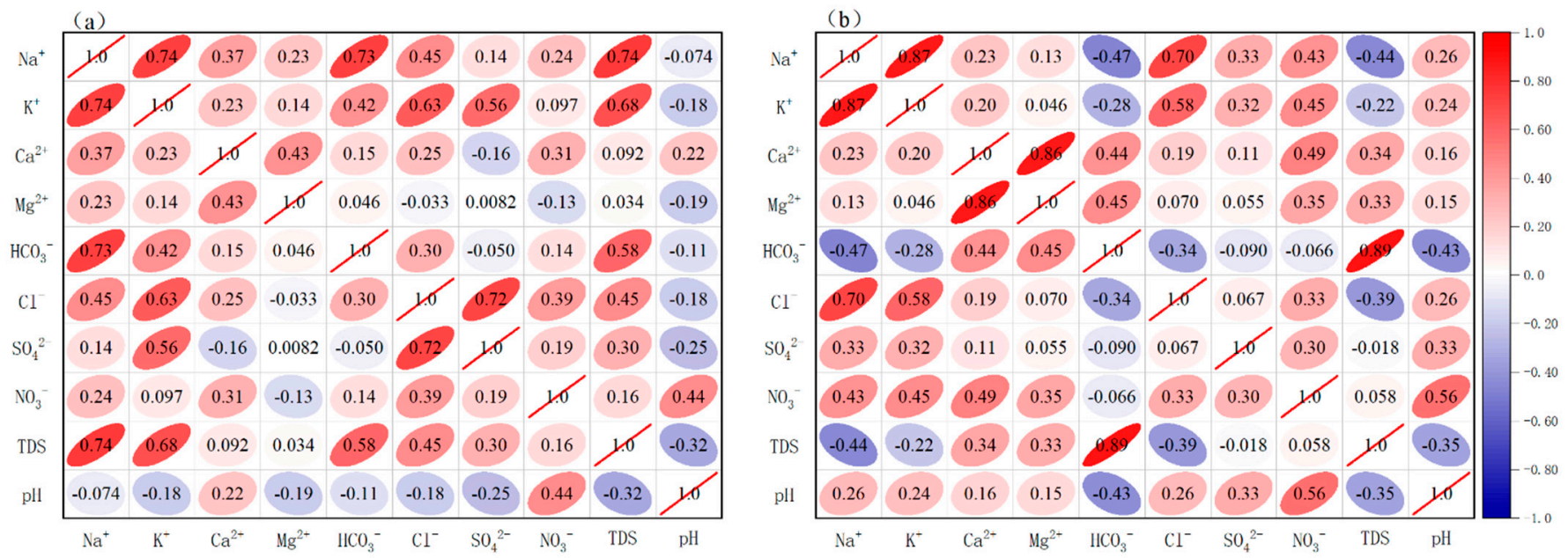

Figure 4. Ion correlation in the water samples: (a) river water ion correlations and (b) spring water ion correlations.

Atmospheric precipitation, evaporite dissolution, rock weathering, and anthropogenic input are the sources of ions in the water column. The source and chemical reaction characteristics can be inferred from the ion content, species, and ratio in the water column $[38,39]$. The main sources of $\mathrm{K}^{+}$and $\mathrm{Na}^{+}$in the water column are atmospheric precipitation, evaporite minerals, and silicate minerals. Numerous studies have shown that the average $\mathrm{Na}^{+} / \mathrm{Cl}^{-}$ value in atmospheric precipitation and seawater is about 0.86 , and when evaporite is dissolved without other influences, the $\left(\mathrm{Na}^{+}+\mathrm{K}^{+}\right) / \mathrm{Cl}^{-}$ratio is about one. In Figure 5, water samples are evenly distributed on both sides of the straight line, but there is no evaporite in the study area, indicating other influences, which will be analyzed below. The ratio of $\left(\mathrm{Na}^{+}+\mathrm{K}^{+}\right) / \mathrm{Cl}^{-}$ and $\mathrm{Na}^{+} / \mathrm{Cl}^{-}$in the water samples in the rainy season is larger than that in the dry season because the water is more affected by humans in summer. In Figure 4, the river water $\mathrm{Na}^{+}$, $\mathrm{K}^{+}$, and $\mathrm{Cl}^{-}$contents are highly correlated, indicating that atmospheric precipitation is the main source of $\mathrm{Na}^{+}, \mathrm{K}^{+}$, and $\mathrm{Cl}^{-}$, being also affected by humans.

When only dolomite is dissolved, the ratio of $\gamma \mathrm{HCO}_{3}{ }^{-}$to $\gamma \mathrm{Ca}^{2+}$ is close to $4: 1$, the ratio of $\gamma \mathrm{HCO}_{3}{ }^{-}$to $\gamma \mathrm{Mg}^{2+}$ is close to 4:1, and the ratio of $\gamma \mathrm{Ca}^{2+}$ to $\gamma \mathrm{Mg}^{2+}$ is close to 1:1. When only calcite is dissolved in groundwater, the ratio of $\gamma \mathrm{HCO}_{3}{ }^{-}$to $\gamma \mathrm{Ca}^{2+}$ is close to 1:2. Since there is no $\mathrm{Mg}$ in calcite $\left(\mathrm{CaCO}_{3}\right)$, the content of $\mathrm{Mg}^{2+}$ in groundwater is low and can be ignored. When calcite $\left(\mathrm{CaCO}_{3}\right)$ and dolomite $\left(\mathrm{CaMg}\left(\mathrm{CO}_{3}\right)_{2}\right)$ dissolve simultaneously in karst groundwater, the ratio of $\gamma \mathrm{HCO}_{3}{ }^{-}$to $\gamma \mathrm{Ca}^{2+}$ is close to 3:1, and the ratio of $\gamma \mathrm{HCO}_{3}{ }^{-}$ to $\gamma \mathrm{Mg}^{2+}$ is close to 6:1. Correlation analysis showed that $\mathrm{Mg}^{2+}, \mathrm{Ca}^{2+}$ and $\mathrm{HCO}_{3}{ }^{-}$are strongly correlated, indicating strong homology. 

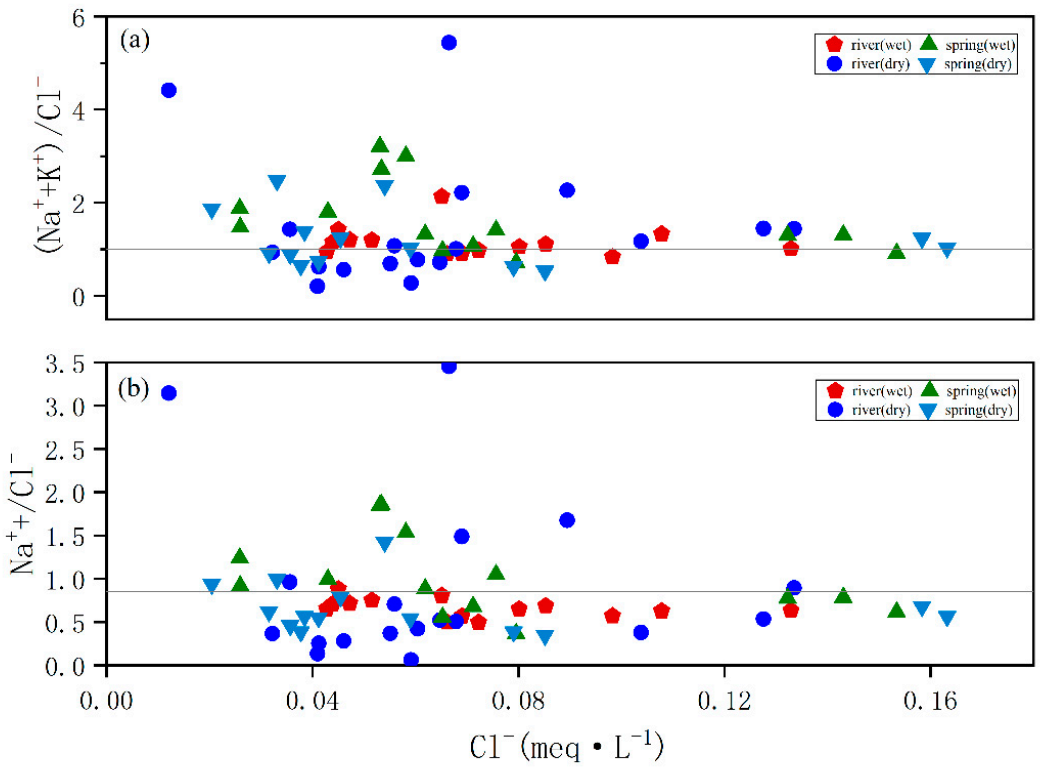

Figure 5. Ion ratio in water samples: (a) $\mathrm{Na}^{+} / \mathrm{Cl}^{-}$and (b) $\left(\mathrm{Na}^{+}+\mathrm{K}^{+}\right) / \mathrm{Cl}^{-}$of the river and spring waters

In Figure $6 \mathrm{a}, \gamma \mathrm{HCO}_{3}{ }^{-}$and $\gamma \mathrm{Ca}^{2+}$ ratios are on either side of the $1: 4$ line, and $\gamma \mathrm{HCO}_{3}{ }^{-}$ and $\gamma \mathrm{Mg}^{2+}$ ratios are below 1:1 and above 1:6, respectively, in Figure 6b, indicating that one of the $\mathrm{Ca}^{2+}$ sources is carbonate rock. The bias is toward the $1: 2$ equivalence in the $\gamma\left(\mathrm{Ca}^{2+}\right.$ $\left.+\mathrm{Mg}^{2+}\right)$ to $\gamma \mathrm{HCO}_{3}{ }^{-}$ratio in Figure $6 \mathrm{c}$. A ratio near $1: 1$ for $\gamma \mathrm{Ca}^{2+}$ to $\gamma \mathrm{Mg}^{2+}$ in Figure $6 \mathrm{~d}$ suggests that the weathered carbonate rock is predominantly dolomite in the study area.
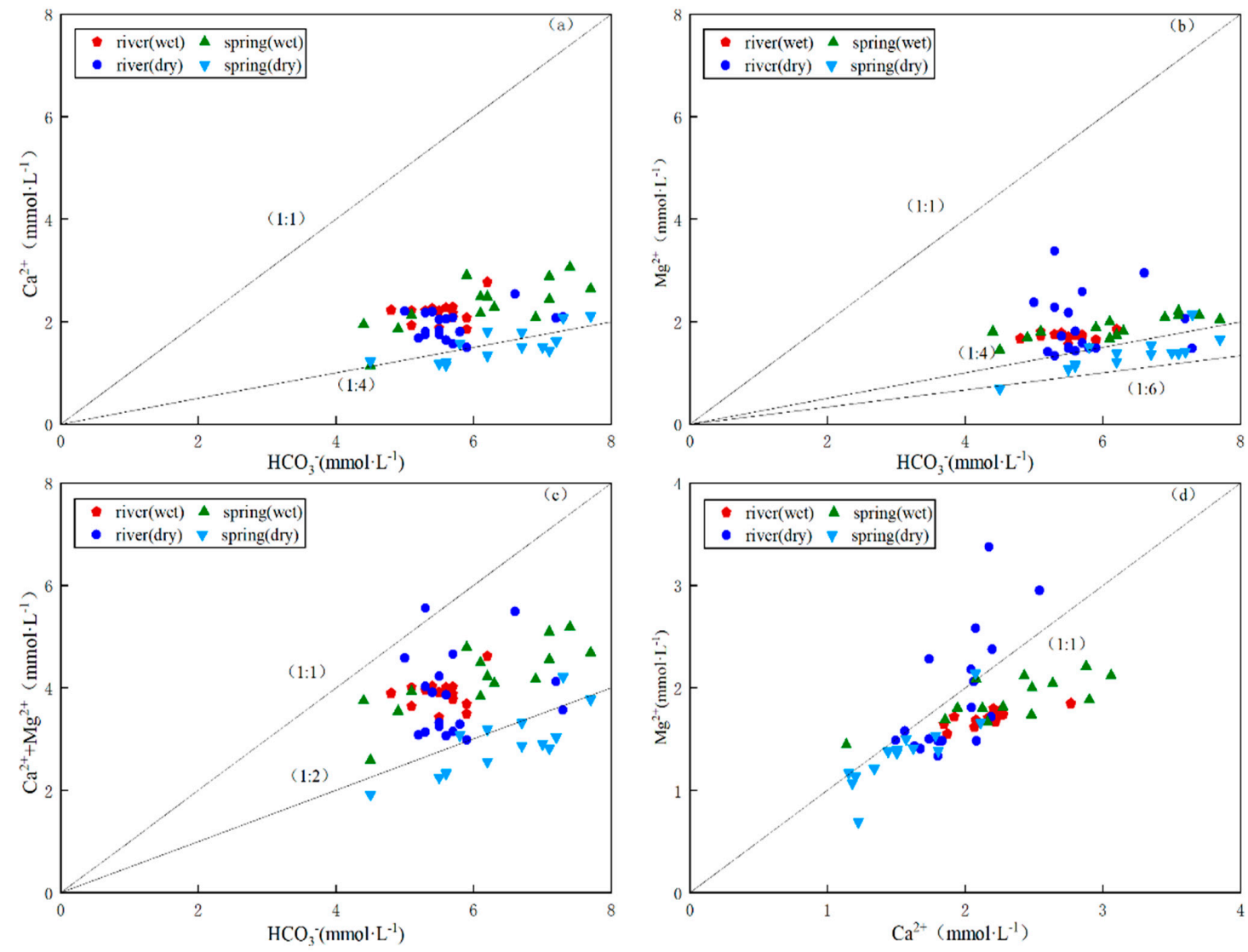

Figure 6. Proportion diagrams of ions with binary hydrogeochemical diagram. (a). $\mathrm{Ca}^{2+} / \mathrm{HCO}_{3}{ }^{-},(\mathbf{b}) . \mathrm{Mg}^{2+} / \mathrm{HCO}_{3}{ }^{-}$, (c) $\left(\mathrm{Mg}^{2+}+\mathrm{Ca}^{2+}\right) / \mathrm{HCO}_{3}{ }^{-}$and $(\mathbf{d}) \mathrm{Mg}^{2+} / \mathrm{Ca}^{2+}$. 


\subsection{Water Chemistry Evolutionary Processes}

Carbonate rocks contain anions on the surfaces of mineral particles, which, under certain conditions, release certain cations from the adsorbed surface and absorb new cations, which is called cation exchange. In general, the $\mathrm{Na}^{+}$and $\mathrm{K}^{+}$contents are relatively low in karst areas, being mainly produced from silicate rocks and evaporite rocks, where evaporation of water or ion exchange with clay minerals can also increase the $\mathrm{K}^{+}$and $\mathrm{Na}^{+}$contents in water [40]. Sodium-calcium exchange can change the concentration of cations in groundwater, an important process in the evolution of water chemistry [41]. The chlor-alkali index (CAI-I and CAI-II) was proposed by Schoeller [42]. If the values of both indices are negative, a certain amount of $\mathrm{Ca}^{2+}$ is replaced by a corresponding amount of $\mathrm{Na}^{+}$in the soil. If the indices are positive, the reaction is occurring in the opposite direction. If a positive exchange occurs between $\mathrm{Na}^{+}$and $\mathrm{K}^{+}$in the groundwater and $\mathrm{Ca}^{2+}$ and $\mathrm{Mg}^{2+}$ in the aquifer, then the index is positive. In Figure 7, the distribution of the water samples shows that a positive exchange as well as a reverse exchange occur, so $\mathrm{Ca}^{2+}$ and $\mathrm{Mg}^{2+}$ are replaced by $\mathrm{Na}^{+}$and $\mathrm{K}^{+}$in the groundwater, explaining why some of the water samples in Figure 5 have a ratio greater than 1 and some have a ratio of less than 1 .

$$
\begin{gathered}
\mathrm{CAI}-\mathrm{I}=\frac{\mathrm{Cl}^{-}-\left(\mathrm{Na}^{+}+\mathrm{K}^{+}\right)}{\mathrm{Cl}^{-}} \\
\text {CAI-II }=\frac{\mathrm{Cl}^{-}-\left(\mathrm{Na}^{+}+\mathrm{K}^{+}\right)}{\mathrm{HCO}_{3}^{-}+\mathrm{SO}_{4}^{2-}+\mathrm{CO}_{3}^{2-}+\mathrm{NO}_{3}^{-}}
\end{gathered}
$$

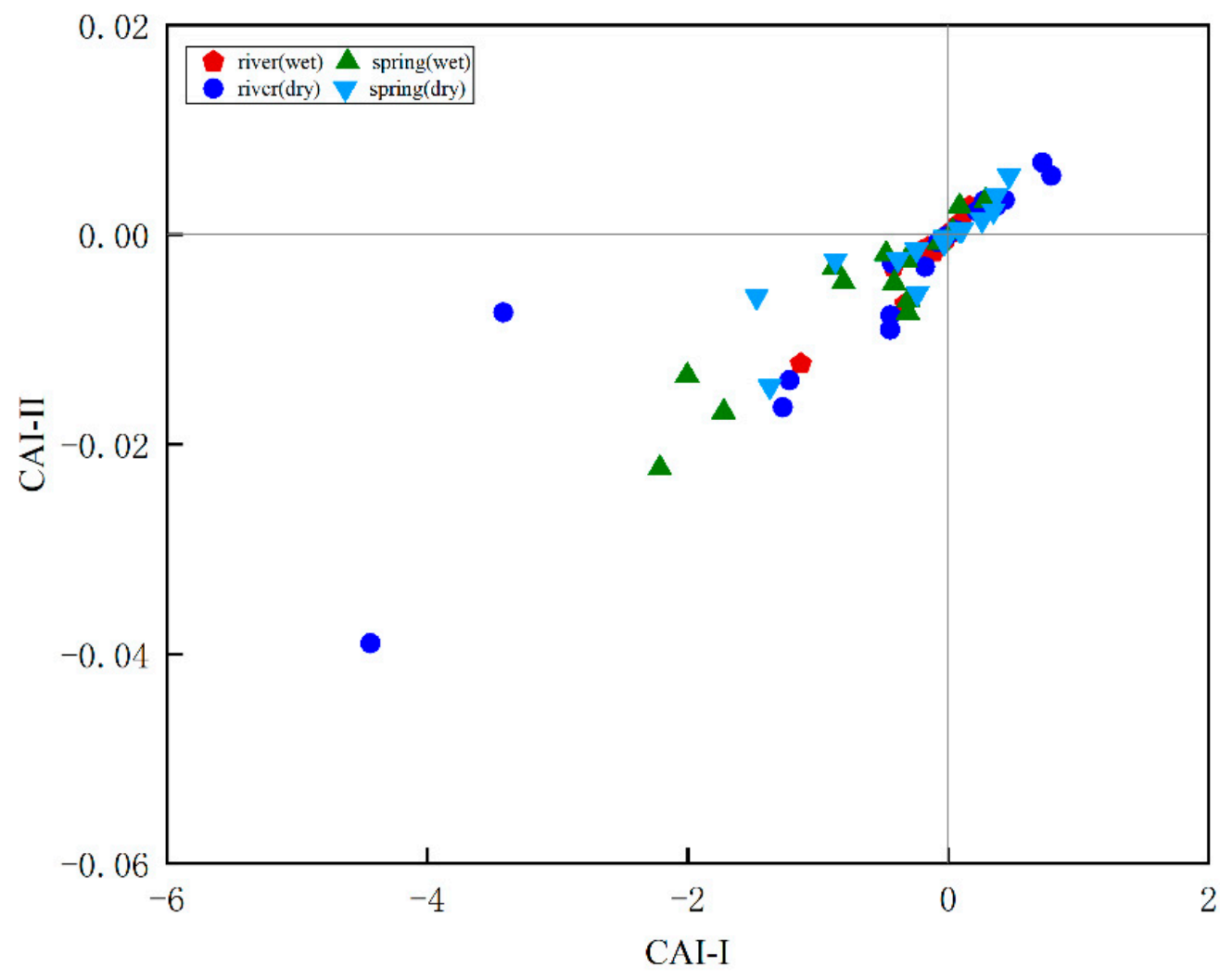

Figure 7. Diagram of chloro-alkaline indices. 
Gibbs diagrams are often used to determine the main controls of the evolution of water chemistry (evaporative crystallization, rock weathering, and atmospheric precipitation effects). The use of ratio plots of ions helps to consider the extent to which seawater, carbonate, and silicate rocks contributed to karst water ion concentrations [5,43]. In the Gibbs diagram, the lower right-hand corner of the diagram is dominated by atmospheric precipitation; in the middle left-hand part of the diagram, such sampling sites are mainly controlled by rock weathering; in the upper right-hand corner of the diagram, such streams are mainly controlled by evaporative crystallization. The scatter diagram is used to determine the main controls (carbonate, silicate, or evaporite) on the weathering process of the rocks. We found that the Huangzhouhe River basin is mainly controlled by rock weathering (Figure 8a,b), while the water samples are distributed in the carbonate rock(Figure 8c,d), indicating that the ionic composition of the water is mainly due to the weathering process of the rocks and is influenced by the weathering of carbonate rocks.
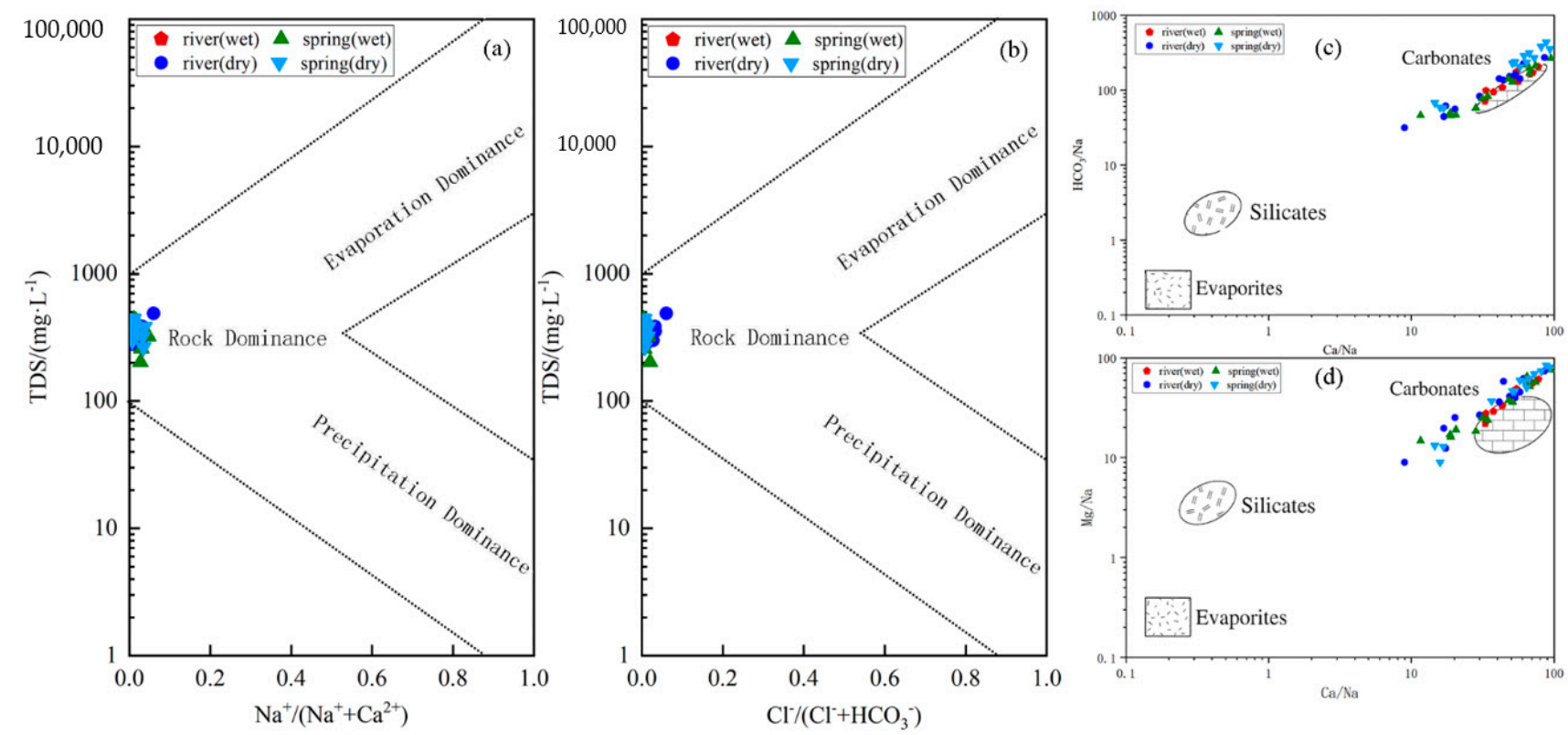

Figure 8. (a,b) Gibbs plots, (c) scatter diagram of $\mathrm{Mg} / \mathrm{Na}$ vs. $\mathrm{Ca} / \mathrm{Na}$, and (d) scatter diagram of $\mathrm{HCO}_{3} / \mathrm{Na}$ vs. $\mathrm{Ca} / \mathrm{Na}$.

\subsection{Impacts of Human Activities on Water Chemistry and Carbon and Nitrogen Contents}

River water chemistry is controlled both by natural geochemistry and by anthropogenic disturbances. It is well known that river ions $\mathrm{Cl}^{-}, \mathrm{SO}_{4}{ }^{2-}$, and DIN are closely related to anthropogenic inputs (both agricultural and industrial) $[8,44]$. The overall sources of ions can be divided into atmospheric precipitation, rock weathering, and external inputs. The sources of $\mathrm{NO}_{3}{ }^{-}$and $\mathrm{SO}_{4}{ }^{2-}$ are mainly rock weathering and anthropogenic inputs, $\mathrm{Cl}^{-}$, and atmospheric inputs. The watershed is mainly subject to the weathering of carbonate rocks. To estimate the contribution of rainfall, the lowest concentrations of $\mathrm{Cl}^{-}\left(0.73 \mathrm{mg} \cdot \mathrm{L}^{-1}\right)$ and $\mathrm{NO}_{3}{ }^{-}\left(1.2 \mathrm{mg} \cdot \mathrm{L}^{-1}\right)$ in the pristine area were assumed to represent atmospheric inputs [45]. The calculations show that the contribution of atmospheric inputs to $\mathrm{Cl}^{-}$and $\mathrm{NO}_{3}{ }^{-}$is less than $5 \%$ of the total dissolved ions. A positive correlation between DOC and $\mathrm{Cl}^{-}$and $\mathrm{SO}_{4}{ }^{2-}$ is clearly shown in Figure 9, indicating anthropogenic pollution from the source. 


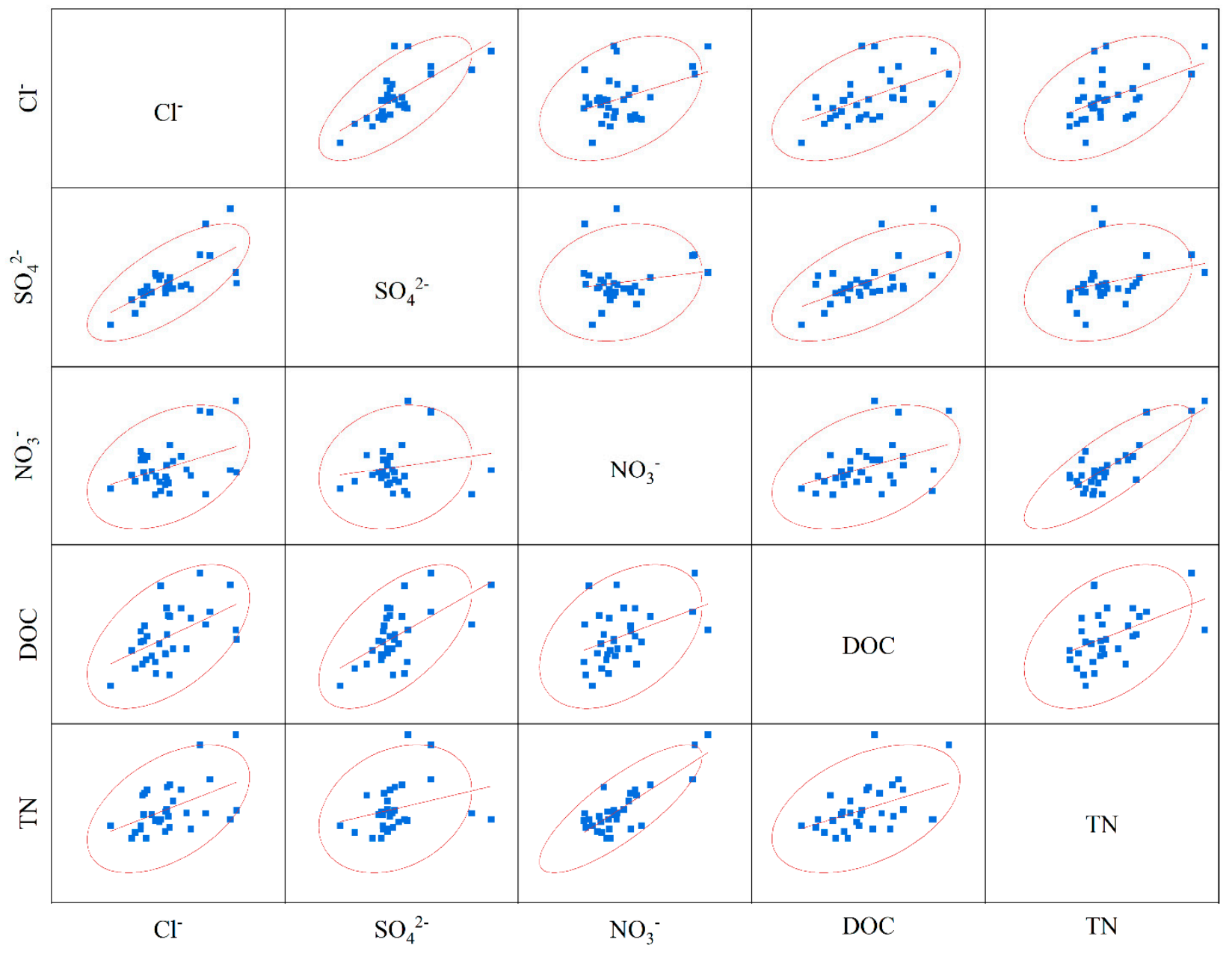

Figure 9. C, N, and ion correlation.

Biological mechanisms of, e.g., phytoplankton and bacteria are considered to be important sources of river DOC [12]. The temporal and spatial changes in river DOC are largely affected by its source. In winter, the average DOC of river water is $3.33 \mathrm{mg} \cdot \mathrm{L}^{-1}$ in the upper reaches and $2.90 \mathrm{mg} \cdot \mathrm{L}^{-1}$ in the middle reaches. The average downstream $\mathrm{DOC}$ is $2.79 \mathrm{mg} \cdot \mathrm{L}^{-1}$. In summer, the average DOC of the river is $3.37 \mathrm{mg} \cdot \mathrm{L}^{-1}, 3.37 \mathrm{mg} \cdot \mathrm{L}^{-1}$, and $2.86 \mathrm{mg} \cdot \mathrm{L}^{-1}$ in the upstream, middle, and downstream areas, respectively, decreasing along the river. The upstream agriculture is mainly rice and tobacco, and there are more phytoplankton in rice. The numbers of villages and farms increase from sampling points 1 to 10 . Domestic sewage is discharged at will, and river water sampling points 9 and 10 are located in towns. Therefore, we found that the DOC is higher upstream. In summer, agricultural and domestic sewage have a greater impact, resulting in more nutrients in the water and greater phytoplankton activity. This led to higher DOC concentrations than in the dry season, but not higher than the world average level of $5.35 \mathrm{mg} \cdot \mathrm{L}^{-1}$ [46], indicating that the Huangzhouhe River is less affected by human activities. With increasing distance from towns and villages, the population density in the middle reaches of the basin decreases, the farmland area decreases, and human pollution decreases. The downstream enters the core protected area, where humans have even less influence. With the gradual reduction in human influence, the river also has the ability to purify itself, so the DOC gradually decreases in the direction of the river. In winter, the average DOC in the upper, middle, and lower spring reaches is $1.75 \mathrm{mg} \cdot \mathrm{L}^{-1}, 3.09 \mathrm{mg} \cdot \mathrm{L}^{-1}$, and $1.70 \mathrm{mg} \cdot \mathrm{L}^{-1}$, respectively. In summer, the average upstream, midstream, and downstream DOC is $2.11 \mathrm{mg} \cdot \mathrm{L}^{-1}$, $3.36 \mathrm{mg} \cdot \mathrm{L}^{-1}$, and $1.75 \mathrm{mg} \cdot \mathrm{L}^{-1}$, respectively. In karst areas, spring water is one of the water sources used in agriculture. Part of the spring water in the middle reaches of the river is 
used on rice fields. At the same time, there are aquatic plants in the spring water. This may be the reason for the high DOC in the spring water in the middle reaches. The upstream and midstream DICs in the watershed remain at the same level due to the influence of domestic sewage. The highest DIC in domestic sewage reaches $7397 \mu \mathrm{mol} \cdot \mathrm{L}^{-1}$, having less of an effect in downstream areas $[47,48]$.

In some river systems such as the Lichunhe and Daguhe Rivers in China, where DIN is the dominant form of $\mathrm{N}$ [36], TN is highly significantly and positively correlated with $\mathrm{NO}_{3}-\mathrm{N}(\mathrm{r}=0.96, p<0.01$; Table 3$)$. $\mathrm{NO}_{3}-\mathrm{N}$ is the main component of DIN, a key nutrient essential for phytoplankton, and its main sources are biological and surface runoff. Changes in $\mathrm{NO}_{3}-\mathrm{N}$ lead to changes in $\mathrm{TN}$, which may be due to the preferential uptake and use of DIN by phytoplankton and bacteria $[49,50]$. River $\mathrm{NO}_{3}-\mathrm{N}$ and TN contents are higher in the middle reaches, where anthropogenic influences are stronger. Downstream in the core protected area, anthropogenic influences are weaker and the self-purification capacity of the river results in decreased levels of $\mathrm{NO}_{3}-\mathrm{N}$ and TN. Spring $\mathrm{NO}_{3}-\mathrm{N}$ and TN contents are the same in the upper stream and midstream and lower in the lower reaches, probably due to a decrease in anthropogenic influences.

Table 3. Pearson correlation coefficients between $\mathrm{C}$ and $\mathrm{N}$ species and physicochemical parameters in the Huangzhouhe River Basin.

\begin{tabular}{|c|c|c|c|c|c|c|c|c|}
\hline Parameters & $T$ & PH & EC & TDS & DIC & DOC & $\mathrm{NO}_{3}-\mathrm{N}$ & TN \\
\hline $\mathrm{T}$ & 1 & & & & & & & \\
\hline $\mathrm{pH}$ & $0.83^{* *}$ & 1 & & & & & & \\
\hline $\mathrm{EC}$ & $0.46^{*}$ & -0.31 & 1 & & & & & \\
\hline TDS & -0.17 & -0.32 & $0.36^{*}$ & 1 & & & & \\
\hline DIC & -0.17 & -0.10 & 0.71 & $0.58^{* *}$ & 1 & & & \\
\hline DOC & 0.20 & 0.77 & 0.32 & $0.35 *$ & -0.08 & 1 & & \\
\hline $\mathrm{NO}_{3}-\mathrm{N}$ & $0.64^{* *}$ & 0.33 & $0.61^{* *}$ & 0.29 & 0.003 & 0.39 * & 1 & \\
\hline TN & $0.67^{* *}$ & 0.42 & $0.56^{* *}$ & 0.27 & 0.14 & 0.42 * & $0.96^{* *}$ & 1 \\
\hline
\end{tabular}

Within the Huangzhouhe River Basin, DOC levels are higher in rivers than in springs, and $\mathrm{TN}$ and $\mathrm{NO}_{3}-\mathrm{N}$ levels are higher in springs than in rivers, mainly because plankton consume DIN to release DOC and because of anthropogenic pollution. Spring DIC levels are significantly higher than those in river water due to the longer duration of water-rock action in springs. The trend in carbon and nitrogen in springs is consistent with that of river water, indicating that springs and river water are independent, interacting, and interdependent in the hydrological system. Compared with river water, spring water is less affected by the outside world. $\mathrm{TN}$ and $\mathrm{NO}_{3}-\mathrm{N}$ are extremely significantly positively correlated ( $\mathrm{r}=0.96, p<0.01$; Table 3 ), with roughly the same range of values, with $\mathrm{NO}_{3}-\mathrm{N}$ accounting for as high as $83 \%$ of the TN. This shows that the output of carbon and nitrogen in the Huangzhouhe River Basin is mainly DIC and $\mathrm{NO}_{3}-\mathrm{N}$.

\subsection{Relationship between $C$ and $N$}

A total of 38 species of algae in the Huangzhouhe River Basin were detected in 6 phyla, 29 families, 37 genera, 5 phyla, 25 genera, and 25 species in summer; 3 phyla, 17 genera, and 18 species in winter. Diatom species are dominant. In summer, diatoms and green algae are positively correlated with $\mathrm{NO}_{3}-\mathrm{N}$; in winter, oscillating algae are mainly negatively correlated with $\mathrm{TN}$ and $\mathrm{NH}_{3}-\mathrm{N}$, and Scenedesmus dimorpha in the phylum Chlorophyta is positively correlated with $\mathrm{NH}_{3}-\mathrm{N}$ [51].

The relationship between water $\mathrm{pH}$ and carbon-to-nitrogen ratio is complex: aquatic plants and animals consume relative levels of $\mathrm{NO}_{3}{ }^{-}$and $\mathrm{NH}_{4}{ }^{+}$and thus have a direct role in regulating water $\mathrm{pH}$, and river $\mathrm{C}: \mathrm{N}$ has an important influence on the growth and reproduction of plankton in water $[52,53]$. Planktonic algae and aquatic plants can absorb and utilize water DIC through photosynthesis [54], so lower levels of planktonic algae 
lead to weaker photosynthesis in the water column, which, in turn, reduces the amount of DIC absorbed and used in the water [55]. These processes inevitably cause changes in the $\mathrm{pH}$ of the water [56], which affect the growth activities of microorganisms and algae $[57,58]$, which affect DOC release and TN decomposition. Dead cells of planktonic algae release high-molecular-weight DOC, while living cells release low-molecular-weight DOC [59]. DOC has an important role in the process of biological denitrification and denitrification [60], where the organic carbon source acts both as an energy source for denitrifying bacteria to synthesize cells and as an electron donor in the denitrification reaction, which can facilitate the conversion of nitrogen in the water column into $\mathrm{N}_{2} \mathrm{O}$ and $\mathrm{N}_{2}$ to be released from the water column into the atmosphere. This reduces the TN content of the water column. There is a correlation between TN and DOC $(r=0.42, p<0.05$; Table 3). Therefore, microorganisms may be the main factor causing carbon and nitrogen coupling in conventional water bodies in the basin. Anthropogenic activities have an impact on water chemistry characteristics, affecting phytoplankton, which, in turn, affects the carbon and nitrogen contents, which, in turn, affect the water chemistry characteristics.

According to the stoichiometric ratio of nutrients in the plant plankton body proposed by Redfield [61], C:N:P = 106:16:1, it can be seen that the C:N suitable for the growth of plankton in the basin water should be about 6.6 The C:N range of the conventional water body of the Huangzhouhe River is 1.7-4.66, with an average of 3.25. Although it has not reached the optimal growth state, good living conditions are provided for plankton, indicating that the pollution caused by human activities is relatively low in the Huangzhouhe River and that the Huangzhouhe River ecosystem is healthy.

\subsection{Water Quality Assessments}

Based on the Sanitary Standards for Drinking Water (GB 5749-2006) [62], some of the water quality parameters $\left(\mathrm{pH}, \mathrm{Cl}^{-}, \mathrm{NO}_{3}-\mathrm{N}, \mathrm{SO}_{4}{ }^{2-}\right.$, and TDS) are shown in Table 4 . The content of $\mathrm{N}$ species in the water samples in the basin is within the standard range, and the DOC content is far less than the average level of $5.35 \mathrm{mg} \cdot \mathrm{L}^{-1}$ in the world's rivers. Shibing is a World Natural Heritage Site, with no serious industrial activities, and only a small area used for traditional agricultural activities. Large areas of virgin forest and diversified ecosystems have been protected and developed, indicating that the world's natural heritage is being protected.

Table 4. Water quality determination $\left(\mathrm{mg} \cdot \mathrm{L}^{-1}\right)$.

\begin{tabular}{cccccc}
\hline Parameter & $\mathbf{p H}$ & $\mathbf{C l}^{-}$ & $\mathbf{N O}_{3}{ }^{-} \mathbf{N}$ & $\mathbf{S O}_{4}{ }^{2-}$ & TDS \\
\hline Standard range & $6.5-8.5$ & $<250$ & $<10$ & $<250$ & $<1000$ \\
Water sample & $6.98-8.99$ & $0.43-5.79$ & $0.15-3.05$ & $4.62-28.53$ & $202.3-488.5$ \\
Unqualified & 1 & 0 & 0 & 0 & 0 \\
\hline
\end{tabular}

\section{Conclusions}

In this study, we found that river and spring water samples within the Huangzhouhe River Basin are dominated by $\mathrm{Ca}^{2+}, \mathrm{Mg}^{2+}$, and $\mathrm{HCO}_{3}{ }^{-} . \mathrm{Ca}^{2+}$ and $\mathrm{Mg}^{2+}$ account for $97 \%$ of the total cation concentration. For anions, $\mathrm{HCO}_{3}{ }^{-}$accounts for about $96 \%$ of the total anion concentration. The higher $\mathrm{HCO}_{3}{ }^{-}$content in the spring water than in the river water is mainly due to the longer duration of spring water-rock action. The water chemistry identified by the Piper diagram is dominated by $\mathrm{HCO}_{3}-\mathrm{Ca}-\mathrm{Mg}$. Through ion correlation, we found that the correlation between $\mathrm{Cl}^{-}$and $\mathrm{SO}_{4}{ }^{2-}$ in river water is stronger than that in spring water, which is due to human influences. The ion ratios, Gibbs plots, and scatter diagram reveal that the water chemistry of the Huangzhouhe River Basin is mainly influenced by the weathering of dolomite rocks, and that cation exchange is also present.

Within the Huangzhouhe River Basin river water, the DOC content decreases gradually in the river direction, mainly due to decreases in population density and anthropogenic impacts. The spring water DOC content is higher in the middle reaches, mainly due to its use for agriculture with more aquatic plants. The river and spring water DIC contents 
increase in midstream areas, which may be due to inputs of domestic wastewater. Due to the impact of agricultural and domestic sewage, the DOC content increases with increases in $\mathrm{Cl}^{-}$and $\mathrm{SO}_{4}{ }^{2-}$. The $\mathrm{TN}$ and $\mathrm{NO}_{3}-\mathrm{N}$ contents in rivers change with the change in population density, reaching a maximum in the middle reaches; the $\mathrm{TN}$ and $\mathrm{NO}_{3}-\mathrm{N}$ contents in spring water are lower downstream. The trends of the changes of the river and spring water contents are the same, with a higher DOC content in river water than in river water, and $\mathrm{NO}_{3}-\mathrm{N}$ leading to less $\mathrm{TN}$ in river water than in spring water, mainly due to the reduction in consumption by plants and organisms' activities in the river. $\mathrm{pH}$ and water temperature affect phytoplankton and bacterial activity, and phytoplankton affect $\mathrm{C}$ and $\mathrm{N}$ concentrations, so microorganisms may be causing carbon and nitrogen coupling in the conventional waters of the basin. The main carbon and nitrogen species in the Huangzhouhe River Basin are $\mathrm{HCO}_{3}{ }^{-}$and $\mathrm{NO}_{3}{ }^{-}$, respectively.

The water quality index content of the Huangzhouhe River Basin complies with Sanitary Standards for Drinking Water (GB5749-2006). Although the Huangzhouhe River is subject to tourism and agricultural impacts, the water quality is still good.

Author Contributions: C.H. writing—original draft preparation, software, and formal analysis; Z.L. conceptualization, methodology, and data curation; K.X. methodology, writing-review and editing, and funding acquisition; X.L. validation, investigation, and supervision; Y.L. investigation, validation, and resources. R.Z. investigation and validation. All authors have read and agreed to the published version of the manuscript.

Funding: This research was supported by the China Overseas Expertise Introduction Program for Discipline Innovation: Overseas Expertise Introduction Center for South China Karst Eco-environment Discipline Innovation(D17016), the Key Science and Technology Program of Guizhou Provence: Poverty Alleviation Model and Technology demonstration for Ecoindustries Derivated from the karst desertification control (No. 54112017 QianKehe Pingtai Rencai), the Technology Program of Guizhou Province: (No. 5726-28 2017 Qiankehe Pingtai Rencai), the Science and Technology Program of Guizhou Province (No. Yiban 1852021 Qiankehe Jichu-ZK), and the Ph.D. Research Startup Foundation of Guizhou Normal University in 2019 (No. GZNUD 22019).

Institutional Review Board Statement: Not applicable.

Informed Consent Statement: Not applicable.

Data Availability Statement: The data presented in this study are available on request from the corresponding author.

Acknowledgments: We appreciate the anonymous reviewers for their invaluable comments and suggestions on this manuscript.

Conflicts of Interest: The authors declare no conflict of interest.

\section{References}

1. White, A.F.; Blum, A.E. Effects of climate on chemical weathering in watersheds. Geochim. Cosmochim. Acta 1995, 59, 1729-1747. [CrossRef]

2. Blum, J.D.; Gazis, C.; Jacobson, A.D.; Chamberlain, C. Carbonate versus silicate weathering in the Raikhot watershed within the High Himalayan Crystalline Series. Geology 1998, 26, 411-414. [CrossRef]

3. West, A.J.; Galy, A.; Bickle, M. Tectonic and climatic controls on silicate weathering. Earth Planet. Sci. Lett. 2005, 235, 211-228. [CrossRef]

4. Riebe, C.S.; Kirchner, J.W.; Finkel, R. Erosional and climatic effects on long-term chemical weathering rates ingranitic land-scapes spanning diverse climate regimes. Earth Planet. Sci. Lett. 2004, 224, 547-562. [CrossRef]

5. Gaillardet, J.; Dupré, B.; Louvat, P.; Allegre, C.J. Global silicate weathering and $\mathrm{CO}_{2}$ consumption rates deduced from the chemistry of large rivers. Chem. Geol. 1999, 159, 3-30. [CrossRef]

6. Tipper, E.T.; Galy, A.; Bickle, M.J. Riverine evidence for a fractionated reservoir of $\mathrm{Ca}$ and $\mathrm{Mg}$ on the continents: Implications for the oceanic Ca cycle. Earth Planet. Sci. Lett. 2006, 247, 267-279. [CrossRef]

7. Ansari, Z.; Ahmad, S. Seasonal Variations of Streams Hydrochemistry and Relationships with Morphometric/Landcover Parameters in the Bhagirathi Watersheds, Garhwal Himalaya, India. J. Geol. Soc. India 2019, 94, 93-500. [CrossRef]

8. $\mathrm{Xu}, \mathrm{Z}$; Liu, C. Chemical weathering in the upper reaches of Xijiang River draining the Yunnan-Guizhou Plateau, Southwest China. Chem. Geol. 2007, 239, 83-95. [CrossRef] 
9. Driscoll, C.T.; Whitall, D.; Aber, J.D.; Boyer, E.W.; Castro, M.; Cronan, C.; Goodale, C.L.; Groffman, P.M.; Hopkinson, C.; Lambert, K.; et al. Nitrogen pollution in the northeastern United States: Sources, effects, and management options. Bioscience 2003, 53, 357-374. [CrossRef]

10. Frost, P.C.; Larson, J.H.; Johnston, C.A.; Young, K.C.; Maurice, P.A.; Lamberti, G.A.; Bridgham, S.D. Landscape predictors of stream dissolved organic matter concentration and physicochemistry in a Lake Superior river watershed. Aquat. Sci. 2006, 68, 40-51. [CrossRef]

11. Neff, J.C.; Chapin III, F.S.; Vitousek, P.M. Breaks in the cycle: Dissolved organic nitrogen in terrestrial ecosystems. Front. Ecol. Environ. 2003, 1, 205-211. [CrossRef]

12. Keller, D.P.; Hood, R.R. Comparative simulations of dissolved organic matter cycling in idealizedoceanic, astal, and estuarine surface waters. Mar. Syst. 2013, 109, 109-128. [CrossRef]

13. Badr, E.S.A. Spatio-temporal variability of dissolved organic nitrogen (DON), carbon (DOC), and nutrients in the Nile River, Egypt. Environ. Monit. Assess. 2016, 88, 580. [CrossRef] [PubMed]

14. Vitousek, P.M.; Aber, J.D.; Howarth, R.W.; Likens, G.E.; Matson, P.A.; Schindler, D.W.; Schlesinger, W.H.; Tilman, D.G. Human alteration of the global nitrogen cycle: Sources and consequences. Ecol. Appl. 1997, 7, 737-750. [CrossRef]

15. Eshleman, K.N.; Hemond, H.F. The role of organic acids in the acid-base status of surface waters at Bickford Watershed, Massachusetts. Water Resour. Res. 1985, 21, 1503-1510. [CrossRef]

16. Roy, R.L.; Campbell, P.G.C. Decreased toxicity of Al to juvenile atlantic salmon (Salmo salar) in acidic soft water containing natural organic matter: A test of the free-ion model. Environ. Toxicol. Chem. 1997, 16, 1962-1969. [CrossRef]

17. Lawlor, A.J.; Tipping, E. Metals in bulk deposition and surface waters at two upland locations in northern England. Environ. Pollut. 2003, 121, 153-168. [CrossRef]

18. McCartney, A.G.; Harriman, R.; Watt, A.W.; Moore, D.W.; Taylor, E.M.; Collen, P.; Keay, E.J. Long-term trends in pH, aluminium and dissolved organic carbon in Scottish fresh waters; implications for brown trout(Salmo trutta) survival. Sci. Total Environ. 2003, 310, 133-141. [CrossRef]

19. Barth, J.A.C.; Cronin, A.A.; Dunlop, J.; Kalin, R.M. Influence of carbonates on the riverine carbon cycle in an anthropogenically dominated catchment basin: Evidence from major elements and stable carbon isotopes in the Lagan River (N. Irel). Chem. Geol. 2003, 200, 203-216. [CrossRef]

20. Leach, J.A.; Larsson, A.; Wallin, M.B.; Nilsson, M.B.; Laudon, H. Twelve years interannual and seasonal variability of stream carbon export from a boreal peatland catchment. Geophys. Res. Biogeosci. 2016, 121, 1851-1866. [CrossRef]

21. Thomas, G.H.; William, B.; George, R.A.; Justin, S.; Li, F.L.; Collin, S.R.; Philip, C. Climate change and dissolved organic carbon export to the Gulf of Mainecarbon export to the Gulf of Maine. Geophys. Res. Biogeosci. 2016, 121, 2700-2716. [CrossRef]

22. Evans, C.D.; Monteith, D.T.; Cooper, D.M. Long-term increases in surface water dissolved organic carbon: Observations, possible causes and environmental impacts. Environ. Pollut. 2005, 137, 55-71. [CrossRef]

23. Lorite-Herrera, M.; Hiscock, K.; Jiménez-Espinosa, R. Distribution of dissolved inorganic and organic nitrogen in river water and groundwater in an agriculturally-dominated catchment, south-East Spain. Water Air Soil Pollut. 2009, 198, 335-346. [CrossRef]

24. Chetelat, B.; Liu, C.Q.; Zhao, Z.Q.; Wang, Q.L.; Li, S.L.; Li, J.; Wang, B.L. Geochemistry of the dissolved load of the Changjiang Basin rivers: Anthropogenic impacts and chemical weathering. Geochim. Cosmochim. Acta 2008, 72, 4254-4277. [CrossRef]

25. Ren, Z.; Qu, X.; Zhang, M.; Yu, Y.; Peng, W.Q. Distinct Bacterial Communities in Wet and Dry Seasons during a Seasonal Water Level Fluctuation in the Largest Freshwater Lake (Poyang Lake) in China. Front. Microbiol. 2019, 10, 1167. [CrossRef]

26. Han, G.; Li, F.; Tan, Q. Effects of land use on water chemistry in a river draining karst terrain, south west China. Hydrol. Sci. 2014, 59, 1063-1073. [CrossRef]

27. Kaushal, S.S.; Duan, S.; Doody, T.R.; Haq, S.; Smith, R.M.; Newcomer, T.A.; Delaney, K.; Gorman, J.; Bowman, N.; Mayer, P.M.; et al. Human-accelerated weathering increases salinization, major ions, and alkalinization in fresh water across land use. Appl. Geochem. 2017, 83, 121-135. [CrossRef]

28. Christophe, R.; Fred, T.M.; Leah, M.V. Influence of the human perturbation on carbon, nitrogen, and oxygen biogeochemical cycles in the global coastal ocean. Geochim. Cosmochim. Acta 2001, 65, 3615-3641. [CrossRef]

29. Zhang, S.; Lu, X.X.; Sun, H.; Han, J.; Laurence, D. Major ion chemistry and dissolved inorganic carbon cycling in a humandisturbed mountainous river (the Luodingjiang River) of the Zhujiang (Pearl River), China. Sci. Total Environ. 2009, 407, $2796-2807$. [CrossRef]

30. Wu, Y.; Bao, H.Y.; Unger, D.; Herbeck, L.S.; Zhu, Z.Y.; Zhang, J.; Jennerjahn, T.C. Biogeochemical behavior of organic carbon in a small tropical river and estuary, Hainan, China. Cont. Shelf Res. 2013, 57, 32-43. [CrossRef]

31. Dinka, O.M.; Loiskandl, W.; Ndambuki, J.M. Hydrochemical characterization of various surface water and groundwater resources available in Matahara areas, Fantalle Woreda of Oromiya region. Hydrol Reg Stud. 2015, 3, 444-456. [CrossRef]

32. Dinka, O.M. Hydrochemical composition and origin of surface water and groundwater in the Matahara area, Ethiopia. Inland Waters 2017, 7, 297-304. [CrossRef]

33. Xiao, S.Z. Chemical Weathering Rate and Karst Carbon Sink of Typical Dolomite Catchment in Subtropical Area: With a Special Reference to Shanmuhe Catchment in Shibing of Guizhou. Ph.D. Thesis, Southwest University, Chongqing, China, 2017.

34. Zhu, X.Q.; Lan, F.N.; Zhao, Y.; Li, Y.Q.; Liu, P.; Hou, S.T.; Wei, M.J.; Yue, X.F. Hydrochemical characteristics and causes of Nandong karst water system in Yunnan Province. Yangtze River 2021, 52, 37-43. [CrossRef]

35. Clark, I.D.; Fritz, P. Environmental Isotopes in Hydrogeology; Lewis Publishers: New York, NY, USA, 1997; pp. 1-352. 
36. Li, K.; Liu, C.; Ma, Y.; Wang, X.L. Land-based dissolved organic nitrogen dynamics and bioavailability in Jiaozhou Bay, China. Estuar. Coast. Shelf Sci. 2019, 220, 13-24. [CrossRef]

37. Lin, G.E.; Wang, T.; Lin, Q.Q.; Han, B.P. Spatial pattern and temporal dynamics of limnological variables in Liuxihe Reservoir, Guangdong. J. Lake Sci. 2009, 21, 387-394. [CrossRef]

38. Zhu, B.; Yang, X.; Rioual, P.; Qin, X.; Liu, Z.; Xiong, H.; Yu, J. Hydrogeochemistry of three watersheds (the Erlqis, Zhungarer and Yili) in northern Xinjiang, NW China. Appl. Geochem. 2011, 26, 1535-1548. [CrossRef]

39. Xing, L.N.; Guo, H.M.; Zhan, Y.H. Groundwater hydrochemical characteristics and processes along flow paths in the North China Plain. J. Asian Earth Sci. 2013, 70-71, 250-264. [CrossRef]

40. Ortega-Guerrero, A. Origin and geochemical evolution of groundwater in a closed-basin clayey aquitard, Northern Mexico. $J$. Hydrol. 2003, 284, 26-44. [CrossRef]

41. Su, Z.; Wu, J.; He, X.; Elumalai, V. Temporal Changes of Groundwater Quality within the Groundwater Depression Cone and Prediction of Confined Groundwater Salinity Using Grey Markov Model in Yinchuan Area of Northwest China. Expo. Health 2020, 12, 447-468. [CrossRef]

42. Schoeller, H. Les Eaux Souterraines; Masson: Paris, France, 1962.

43. Gibbs, R.J. Mechanisms Controlling World Water Chemistry. Science 1970, 170, 1088-1090. [CrossRef] [PubMed]

44. Jiang, Y. The contribution of human activities to dissolved inorganic carbon fluxes in a karst underground river system: Evidence from major elements and $\delta^{13} \mathrm{C}$-DIC in Nandong, Southwest China. J. Contam. Hydrol. 2013, 152, 1-11. [CrossRef]

45. Moon, S.; Huh, Y. Chemical weathering in the Hong (Red) River basin: Rates of silicate weathering and their controlling factors. Geochim. Cosmochim. Acta 2007, 71, 1411-1430. [CrossRef]

46. Meybeck, M. Carbon, nitrogen, and phosphorus transport by world rivers. Am. J. Sci. 1982, 282, 401-450. [CrossRef]

47. Li, X.Q.; Han, G.L.; Liu, M.; Song, C.; Zhang, Q.; Yang, Y.G.; Liu, J.K. Hydrochemistry and Dissolved Inorganic Carbon (DIC) Cycling in a Tropical Agricultural River, Mun River Basin, Northeast Thailand. Int. J. Environ. Res. Public Health 2019, 16, 3410. [CrossRef]

48. Shin, W.J.; Lee, K.S.; Park, Y.; Lee, D.; Yu, E.J. Tracing anthropogenic DIC in urban streams based on isotopic and geochemical tracers. Environ. Earth Sci. 2015, 74, 2707-2717. [CrossRef]

49. Kirchman, D.L.; Wheeler, P.A. Uptake of ammonium and nitrate by heterotrophic bacteria and phytoplankton in the sub-Arctic Pacific. Deep Sea Res. Part I Oceanogr. Res. Pap. 1998, 45, 347-365. [CrossRef]

50. Middelburg, J.J.; Nieuwenhuize, J. Uptake of dissolved inorganic nitrogen in turbid, tidal estuaries. Mar. Ecol. Prog. Ser. 2002, 192, 79-88. [CrossRef]

51. Zhang, C.Y. River Water Environment Quality Monitoring and Health Evaluation Index System Construction in Karst Area. Master's Thesis, Guizhou Normal University, Guizhou, China, 2019.

52. Satoh, H.; Okabe, S.; Norimatsu, N.; Watanabe, Y. Significance of Substrate C/N Ratio on structure and activity of nitrifying biofilms determined by in situ hybridization and the use of microelectrodes. J. Jpn. Soc. Water Environ. 2000, 41, 317-321. [CrossRef]

53. Dila, D.K.; Biddanda, B.A. From land to lake: Contrasting microbial processes across a Great Lakes gradient of organic carbon and inorganic nutrient inventories. J. Great Lakes Res. 2015, 41, 75-85. [CrossRef]

54. Zheng, J. The Influence of Biogeochemical Behavior of Aquatic Plants on Karst Carbon Sink. Master's Thesis, Southwest University, Chongqing, China, 2014.

55. Yang, C.; Telmer, K.; Veizer, J. Chemical dynamics of the “St. Lawrence" riverine system: $\delta \mathrm{DH}^{2} \mathrm{O}, \delta^{18} \mathrm{O}_{\mathrm{H} 2 \mathrm{O}}, \delta^{13} \mathrm{CDIC}, \delta^{34} \mathrm{Ssulfate}$, and dissolved ${ }^{87} \mathrm{Sr} /{ }^{86} \mathrm{Sr}$. Geochim. Et Cosmochim. Acta 1996, 60, 851-866. [CrossRef]

56. Liu, S.N.; An, S.Q.; Yan, Z.B.; Ren, J.P.; Lu, X.Q.; Ge, F.Y.; Han, W.X. Variation and potential influence factors of foliar pH in land-water ecozones of three small plateau lakes. Plant Ecol. 2021, 14, 504-514. [CrossRef]

57. Whitton, B.A.; Potts, M. The Ecology of Cyanobacteria; Springer: Dordrecht, The Netherlands, 2002; pp. 149-194.

58. Zhao, L.F.; Zhu, W.; Mo, M.X. Effects of submerged macrophytes on $\mathrm{pH}$ values and nitrogen removal. Water Resour. Prot. 2008, 24, 64-67.

59. Ye, L.L.; Shi, X.L.; Wu, X.D.; Li, D.M.; Yu, Y.; Kong, M.F. The effect of cyanobacteria on dissolved organic carbon post the bloom in autumn in Western Lake Taihu, China. Environ. Sci. 2011, 31, 131-136.

60. Rui, Y.L. Pilot-Scale Study on Denitrification Technology of Shallow Groundwater in the Lakeside of Lake Dianchi. Master's Thesis, Yunnan University, Kunming, China, 2016.

61. Redfield, A.C.; Ketchum, B.H.; Richards, F.A. The influence of organisms on the composition of sea-water. Sea 1963, 2, 26-77.

62. Ministry of Health of the People's Republic of China Standardization Administration. Standards for Drinking Water Quaity (GB5749-2006); Standards Press of China: Beijing, China, 2007. 